
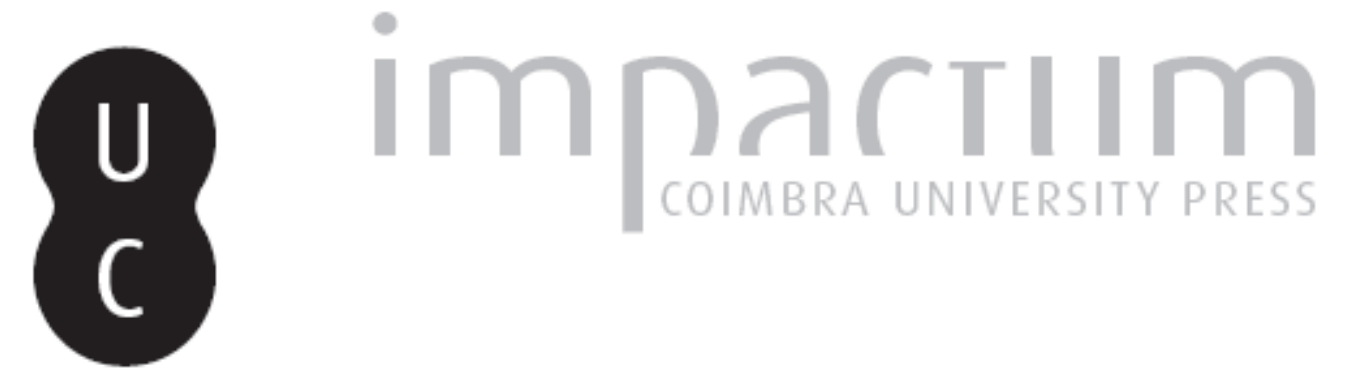

Cribra and trace elements in the Prat de la Riba Necropolis (Tarragona, Spain, 3rd-5th centuries AD)
Autor(es):
Garcia, Elena; Berrocal, Maria Isabel; Baxarias, Joaquim; Campillo, Domènec; Subirà, Maria Eulàlia

Publicado por: CIAS - Centro de Investigação em Antropologia e Saúde

URL

persistente:

URI:http://hdl.handle.net/10316.2/41263

DOI:

DOI:http://dx.doi.org/10.14195/2182-7982_19_7

Accessed : $\quad$ 26-Apr-2023 14:10:18

A navegação consulta e descarregamento dos títulos inseridos nas Bibliotecas Digitais UC Digitalis, UC Pombalina e UC Impactum, pressupõem a aceitação plena e sem reservas dos Termos e Condições de Uso destas Bibliotecas Digitais, disponíveis em https://digitalis.uc.pt/pt-pt/termos.

Conforme exposto nos referidos Termos e Condições de Uso, o descarregamento de títulos de acesso restrito requer uma licença válida de autorização devendo o utilizador aceder ao(s) documento(s) a partir de um endereço de IP da instituição detentora da supramencionada licença.

Ao utilizador é apenas permitido o descarregamento para uso pessoal, pelo que o emprego do(s) título(s) descarregado(s) para outro fim, designadamente comercial, carece de autorização do respetivo autor ou editor da obra.

Na medida em que todas as obras da UC Digitalis se encontram protegidas pelo Código do Direito de Autor e Direitos Conexos e demais legislação aplicável, toda a cópia, parcial ou total, deste documento, nos casos em que é legalmente admitida, deverá conter ou fazer-se acompanhar por este aviso.

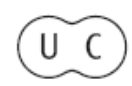


Antropologia Portuguesa

Volume $19 \cdot 2002$

Departamento de Antropologia | Universidade de Coimbra 


\title{
Cribra and trace elements in the Prat de la Riba Necropolis (Tarragona, Spain, $3^{\text {rd }}-5^{\text {th }}$ centuries AD)
}

\author{
Elena Garcia 1 ,2,3, Maria Isabel Berrocal'1,2, Joaquim Baxarias², \\ Domènec Campillo², Maria Eulàlia Subirà. ${ }^{1,2}$ \\ 'Unitat d'Antropologia. Departament de Biologia Animal, Biologia Vegetal i Ecologia. \\ Facultat de Cjencies. Edifici C. Universitat Autonoma de Barcelona \\ 08193 Bellaterra (Barcelona), Spain \\ 2 Lahoratori de Paleopatologia i P’aleoantropologia \\ Museu d'Arupueologia de Catalunya, Spain \\ ${ }^{3}$ Archaedsogical Sciences Department University of Bradford, United Kingdom \\ elent.garciagecampus.uab.es
}

\begin{abstract}
The different kinds of cribra are manifestations of porotic hyperostosis on the orbital roof (cribra orbitalia), on the femur neck (cribri femoralis) or on the humerus head (cribra humeralis). The aetiology of cribra is not clear. Some authors attribute the presence of cribra to anaemia (infectious or genetic) while others consider it the consequence of nutritional deficit. The analysis of trace elements in human bones may help to reveal the aetiology of cribr. This study analyzes the prevalence of cribra related to trace element levels in a Spanish late Roman necropolis $\left(3^{\text {rd }}-5^{\text {th }}\right.$ centuries $A D$ ). The results show no association between the different kinds of cribra and nutritional deficiency.
\end{abstract}

Key words Paleopathology; cribrn; trace elements; Tarragona; Late Roman Necropolis.

Resumo Os diferentes tipos de cribra são manifestações de hiperostose porótica localizadas nas fossas orbitárias (cribra orbitalia), no colo femoral (cribra femoralis) ou na cabeça do úmero (cribra Immeralis). A etiologia da cribra nāo é clara. Alguns autores atribuem a presença de cribra a anemia (infecciosa ou genética), enquanto outros a consideram resultante de um défice nutricional. A análise de oligoelementos nos ossos humanos pode contribuir para revelar a etiologia da cribra. Esta metodologia foi utilisada no espólio de uma necrópole Tardo-Romana Espanhola dos séculos III-V d.C.. Os resultados obtidos mostraram nāo haver associação entre a incidência dos diferentes tipos de cribra e a deficiência nutricional.

Palavras-chave Paleopatologia; cribra; oligoelementos; Necrópole TardoRomana; Tarragona. 


\section{Introduction}

Trace elements are defined as those occurring in amounts of less than $0.01 \%$ of the human body mass (Gilbert, 1985). They can contribute significantly to paleopathological analyses because of their associations with the biological conditions of humans groups, prehistoric diets and the aetiology of different illnesses. Multielemental analyses are employed in paleopathology both to discover the relationship between nutrition and illness, and to estimate the effect of chemical deficiencies or excesses in the organism (Carlson et al., 1974; Fornaciari et al., 1981; Von Endt and Ortner, 1982; Gilbert, 1985; Subirà et al., 1992; Gleń-Haduch et al., 1997). Normal growth and development, and the maintenance of good health, depend upon an adequate supply of the essential trace elements (Waldron, 1987). Excess or deficiency of those elements in the diet could play a negative part in the development of whole populations (Smrčka et al., 1989).

Although paleopathology is aimed at evaluation of disease in excavated skeletons, the detectable macro- or microscopic symptoms are often not very specific. Plausibility of diagnosis is increased if other background information is available. We therefore combine two methods - paleopathology and chemical analyses of excavated skeletons - to identify the causes of disease in past populations (Hühne-Osterloh and Grupe, 1989).

In this study we analyse three pathological lesions: cribra orbitalia, cribra femoralis and cribra humeralis. The different kinds of cribra are considered to be markers of either nutritional deficiencies or physiological stress (Hengen, 1971; Carlson et al., 1974; El-Najjar et al., 1975; El-Najjar, 1976; El-Najjar et al., 1976; El-Najjar and Robertson, 1976; Lallo et al., 1977; Stuart-Macadam, 1982. Cohen and Armelagos, 1984; Campillo, 1993; 2001). Other authors attributed the cribra to genetic or infectious anaemia (Moore, 1929; Smith, 1954; Angel, 1966; 1971; 1984; Weinberg, 1974; StuartMacadam, 1982; 1992).

Cribra orbitalin is a form of porotic hyperostosis present on the orbital roof, whose aetiology is still rather obscure, although most authors accept that it is related to genetic or infectious anaemia. 
Stuart-Macadam (1992) has reported three major trends in the occurrence of porotic hyperostosis: temporal, geographic and ecological. Cribrn femoralis is another form of porotic hyperostosis, observed on a specific zone in the femur neck; it seems to be more frequent in sub-adults. The third form, cribra humernlis, has been described only recently in the paleopathological literature (Baxarias, 2001). This form is located in the internal anterior region of humerus head, near the metaphysis.

For this study we analized the population of Prat de la Riba, a great necropolis which is very well suited for this kind of study, not only for the good state of bone preservation, but also for the high number of skeletons recovered and for their careful excavation and prior study. The necropolis of Prat de la Riba is located in the city of Tarragona (Spain) and it is part of a huge cementerial area called Necropolis del Francolí. In the Prat de la Riba necropolis were found 220 burials which contained 243 skeletons. The site was dated using the Keay typological systematization classification of the amphoric containers. It was occupied for a long period of time during the Late Roman period, from the end of the $3^{\text {rd }}$ century a.C. to the end of the $5^{\text {th }}$ century a.C. (Foguet and Vilaseca, 1995).

The main goal of this study is to examine the relationship between the lesions of cribra orbitalin, cribrn femoralis and cribra humeralis and the concentration of selected trace elements in human skeletons from the Prat de la Riba necropolis.

\section{Material and method}

For this study, we submitted human bone samples from 118 individuals, both pathological and non-pathological, for chemical analysis of trace elements (Table 1). The chemical elements chosen for this study were: calcium (expressed in percentage in one bone gram), strontium, barium, zinc, copper and magnesium (quantified in parts per million, ppm). Iron would have been a very interesting element to include in this type of study because of its relationship to iron deficiency anaemia. However, this element 
is very difficult to quantify using standard trace elements methodology because it is very subject to diagenesis, and so it was excluded (Lambert and Weydert-Homeyer, 1993; Price and Kavanagh, 1982). For this analysis we sampled the right femur of each of the 118 individuals because it was more often present than other bones in the skeletal remains. Before the chemical analysis, the surface of each bone sample was removed to eliminate possible contamination. The chemical method used for bone analysis was the one established in the Unitat d'Antropologia in the Biology Department of the Lniversitnt Autònoma de Barcelona (Subirà, 1993). The trace elements were quantified using an ICP/AES Spectrometer at the Serveis Cientifico-Tecnics of the Universitat de Barcelona. A complete anthropological analysis, which includes anthropometric, demographic, nutritional and paleopathological data, was previously performed for the skeletal individuals in the Museu d'Arqueologia de Barcelonn.

Table 1. Distribution of the human bone samples studied.

\begin{tabular}{lccccccc}
\hline Sex/Age & Infantile I & Infantile II & Juvenile & Adult & Mature & Senile & TOTAL \\
\hline Female & 0 & 5 & $\mathbf{1 7}$ & 18 & 15 & 3 & 58 \\
Male & 1 & 6 & 7 & 14 & 18 & 3 & 49 \\
Indeterminate & 6 & 4 & 1 & 0 & 0 & 0 & 11 \\
\hline TOTAL & 7 & $\mathbf{1 5}$ & $\mathbf{2 5}$ & $\mathbf{3 2}$ & $\mathbf{3 3}$ & $\mathbf{6}$ & $\mathbf{1 1 8}$ \\
\hline
\end{tabular}

The range ages are: Infantile I: 0-6 years; Infantile II: 7-12 years; Juvenile: 13-20 years; Adult: $21-40$ years; Mature: $41-60$ years; Senile: $61-80$ years. For estimation of sex we used the skull and pubis morphology for the adults and the jaw and pubis morphology for the sub-adults (Schutkowsky, 1993).

The distributions of the concentrations of trace elements were first analysed by Kolmogorov-Smirnov tests (SPSS 11.5.1). The concentrations of barium, strontium, magnesium, copper and calcium (but not zinc) were normally distributed, so they were further analysed using parametrical tests. For zinc, a nonparametrical test was employed. 


\section{Results and discussion}

Before comparing the levels of trace elements with the presence/absence of cribra it is necessary to know the demographic profile of the sampled population, to determine if different concentrations of trace elements are associated with sex or age in the sample. The presence of different elemental concentrations can be attributed either to physiology or to diet. No relationship was found between the levels of barium, calcium, copper, magnesium, zinc and strontium and the sex of the specimens when ANOVA analysis was applied, although the males have slightly higher levels of all elements except calcium. As for age, all elements showed higher levels in sub-adults than in adults, except for calcium. Magnesium initially showed a significant difference in concentration between age groups $(\mathrm{P}=0,037)$ but when a Post Hoc test (Tukey) was applied in order to evaluate in greater detail the inter-group variation, the differences were no longer significant. However, significant differences in concentrations between the age groups for copper remained consistent, detected through ANOVA analysis (Table 2). Infants and juveniles showed higher copper levels than mature and elderly adults. These different age-related patterns probably reflect both physiology and diet. Neonates and infants show a generalized tendency towards higher tissue levels of essential elements which gradually decline with age towards the adult levels. This temporal change in tissue levels is reflected in the concentrations in the skeleton (Waldron, 1987). When infants are weaning they may be fed additional foods like cow's milk and cereal gruels (Hühne-Osterloh and Grupe, 1989). Cereals are very rich in copper, and their consumption may explain the higher levels of copper found in the infantile group. This same pattern has been reported at other sites such as Can Martorell (Barcelona, Spain) and Can Reinés (Mallorca, Spain) (Garcia and Subirà, 2001; Subirà and Garcia, 2003). 
Table 2. Statistical values of trace elements by age groups.

\begin{tabular}{|c|c|c|c|c|c|c|}
\hline T. E. & Age groups & $\mathrm{N}$ & Mean & $\begin{array}{l}\text { Standard } \\
\text { deviation }\end{array}$ & $\mathbf{F}$ & $\mathbf{P}$ \\
\hline \multirow[t]{7}{*}{ Ba } & Infantile I & 7 & 799,947 & 411,580 & $0,507^{1}$ & 0,771 \\
\hline & Infantile II & 15 & 659,833 & 229,722 & & \\
\hline & Juvenile & 25 & 670,418 & 371,425 & & \\
\hline & Adult & 32 & 756,005 & 379,473 & & \\
\hline & Mature & 33 & 659,130 & 337,660 & & \\
\hline & Senile & 6 & 622,750 & 217,288 & & \\
\hline & TOTAL & 118 & 694,386 & 342,418 & & \\
\hline \multirow[t]{7}{*}{$\mathrm{Cu}$} & Infantile I & 7 & 107,452 & 28,541 & $8,045^{1}$ & 0,000 \\
\hline & Infantile II & 15 & 87,453 & 37,888 & & \\
\hline & Juvenile & 25 & 80,718 & 23,200 & & \\
\hline & Adult & 32 & 63,730 & 21,204 & & \\
\hline & Mature & 33 & 56,577 & 21,956 & & \\
\hline & Senile & 6 & 77,717 & 13,757 & & \\
\hline & TOTAL & 118 & 71,649 & 28,150 & & \\
\hline \multirow[t]{7}{*}{$\mathrm{Mg}$} & Infantile I & 7 & 1672,225 & 127,009 & $2,469 !$ & 0,037 \\
\hline & Infantile II & 15 & 1700,267 & 299,411 & & \\
\hline & Juvenile & 25 & 1514,600 & 182,707 & & \\
\hline & Aadult & 32 & 1613,672 & 247,411 & & \\
\hline & Mature & 33 & 1584,606 & 181,321 & & \\
\hline & Senile & 6 & 1806,917 & 352,966 & & \\
\hline & TOTAL & 118 & 1608,861 & 233,089 & & \\
\hline \multirow[t]{7}{*}{$\mathrm{Sr}$} & Infantile I & 7 & 670,884 & 124,952 & $1,410^{1}$ & 0,226 \\
\hline & Infantile II & 15 & 808,533 & 217,391 & & \\
\hline & Juvenile & 25 & 750,472 & 184,095 & & \\
\hline & Adult & 32 & 835,922 & 204,415 & & \\
\hline & Mature & 33 & 782,726 & 211,132 & & \\
\hline & Senile & 6 & 912.250 & 313.146 & & \\
\hline & TOTAL & 118 & 793,550 & 208,407 & & \\
\hline \multirow[t]{7}{*}{$\mathrm{Ca}$} & Infantile I & 7 & 29,969 & 3,139 & $1,941^{1}$ & 0,093 \\
\hline & Infantile II & 15 & 29,541 & 2,109 & & \\
\hline & Juvenile & 25 & 30,364 & 2,182 & & \\
\hline & Adult & 32 & 31,461 & 1,918 & & \\
\hline & Mature & 33 & 30,242 & 2,661 & & \\
\hline & Senile & 6 & 29,789 & 1,511 & & \\
\hline & TOTAL & 118 & 30,470 & 2,336 & & \\
\hline \multirow[t]{7}{*}{$\overline{\mathrm{Zn}}$} & Infantile I & 7 & 169,204 & 35,640 & 2,9422 & 0,709 \\
\hline & Infantile II & 15 & 176,893 & 44,567 & & \\
\hline & Juvenile & 25 & 192,192 & 49,766 & & \\
\hline & Adult & 32 & 180,242 & 45,738 & & \\
\hline & Mature & 33 & 193,453 & 77,596 & & \\
\hline & Senile & 6 & 244,633 & 112,703 & & \\
\hline & TOTAL & 118 & 297,824 & 26,571 & & \\
\hline
\end{tabular}

T.E. - trace elements; Ba - barium; $\mathrm{Cu}$ - cooper; $\mathrm{Mg}$ - magnesium; $\mathrm{Sr}$ - strontium; $\mathrm{Ca}$ - calcium; $\mathrm{Zn}$ - zinc. (1) ANOVA Tesit; (2) Kruskal Wallis Test. 
Among the late Roman remains from Prat de la Riba, $10 \%$ of the specimens displayed cribra orbitalia (12/124 cases observed). There was no difference between males and females in the frequency of occurrence of this pathology. However, cribra orbitalin was more frequently observed in skulls of individuals less than twenty years old (Baxarias, 2001). Trace elements levels do not differ significantly between individuals with cribra orbitalia and without the lesions when analyzed by Student's t-test (Table 3).

Table 3. Statistical values of trace elements and cribra orbitalia and Student's t-test.

\begin{tabular}{|c|c|c|c|c|c|c|}
\hline T. E. & $\begin{array}{c}\text { cibra } \\
\text { orbitalia }\end{array}$ & $\mathbf{N}$ & Mean & $\begin{array}{l}\text { Standard } \\
\text { deviation }\end{array}$ & Student's t-test & $P$ \\
\hline \multirow[t]{2}{*}{$\mathrm{Ba}$} & No & 102 & 699,522 & 341,325 & 0,638 & 0,525 \\
\hline & Yes & 12 & 633,321 & 326,676 & & \\
\hline \multirow[t]{2}{*}{$\mathrm{Cu}$} & No & 102 & 69,831 & 26,114 & $-1,444$ & 0,152 \\
\hline & Yes & 12 & 81,363 & 26,676 & & \\
\hline \multirow[t]{2}{*}{$\mathrm{Mg}$} & No & 102 & 1607,158 & 220,776 & 0.129 & 0,897 \\
\hline & Yes & 12 & 1597,958 & 325,584 & & \\
\hline \multirow[t]{2}{*}{$\mathrm{Sr}$} & No & 102 & 785,214 & 208,104 & $-0,734$ & 0,465 \\
\hline & Yes & 12 & 831,804 & 207,129 & & \\
\hline \multirow[t]{2}{*}{$\mathrm{Ca}$} & No & 102 & 30,485 & 2,407 & $-0,026$ & 0,979 \\
\hline & Yes & 12 & 30,504 & 2,062 & & \\
\hline \multirow[t]{2}{*}{$\mathrm{Zn}$} & No & 102 & 191,193 & 64,402 & 500,5 (1) & 0,301 \\
\hline & Yes & 12 & 172,200 & 34,929 & & \\
\hline
\end{tabular}

I U Mann-Whitney Test

In the studied population, cribrn femoralis is present in $27 \%$ of the skeletons (31/113 cases observed). No relationship between the presence or absence of cribrn femoralis and the sex of the specimens was found. On the other hand, in this necropolis there exists an association between cribrn orbitnlin and cribra fentoralis (Baxarias, 2001). When a Student's $t$-test was applied, a significantly higher level of copper was found in the skeletons with cribra femoralis (Table 4). Ninety-four percent of the individuals with this pathology are infants and juveniles, who also show higher levels of copper than do the adults in the sample. When we only consider the sub-adult group, no differences were found in the level of copper between the individuals with and without this pathology. 
Table 4. Statistical values of trace elements and cribra femoralis and Student's-Test.

\begin{tabular}{lcrrrrc}
\hline T. E. & $\begin{array}{c}\text { Coribra } \\
\text { fcmoralis }\end{array}$ & $\mathbf{N}$ & Mean & $\begin{array}{c}\text { Standard Student's t-lest } \\
\text { deviation }\end{array}$ & $\mathrm{P}$ \\
\hline $\mathrm{Ba}$ & No & 82 & 672,192 & 328,568 & $-0,997$ & 0,321 \\
& Yes & 31 & 743,468 & 366,429 & & \\
\hline $\mathrm{Cu}$ & No & 82 & 66,303 & 26,321 & $-2,831$ & 0,006 \\
& Yes & 31 & 81,706 & 24,384 & & \\
\hline $\mathrm{Mg}$ & No & 82 & 1618,043 & 246,242 & 0,538 & 0,592 \\
& Yes & 31 & 1591,451 & 199,301 & & \\
\hline $\mathrm{Sr}$ & No & 82 & 780,024 & 212,915 & $-0,827$ & 0,410 \\
& Yes & 31 & 816,710 & 203,420 & & \\
\hline $\mathrm{Ca}$ & No & 82 & 30,733 & 2,537 & 1,597 & 0,113 \\
& Yes & 31 & 29,943 & 1,734 & & \\
\hline $\mathrm{Zn}$ & No & 82 & 189,349 & 66,569 & $1215,500(1)$ & 0,721 \\
& Yes & 31 & 182,205 & 47,227 & & \\
\hline
\end{tabular}

'U Masn-Whitney Test

In the Prat de la Riba population, $3 \%$ of the individuals show cribra humeralis (3/112 cases observed). One case also shows evidence of chronic osteomyelitis. There is one hundred percent statistical association between cribra femornlis and cribra humeralis. We found no difference in the levels of any particular element between specimens with pathological changes and healthy specimens, using Student's t-test analysis (Table 5).

Table 5. Statistical values of trace elements and cribra humeralis and Student's t-test.

\begin{tabular}{lcrrrrc}
\hline T. E. & $\begin{array}{c}\text { cribra } \\
\text { lumernlis }\end{array}$ & $\mathbf{N}$ & Mean & $\begin{array}{l}\text { Standard Student's t-test } \\
\text { deviation }\end{array}$ & $\mathbf{P}$ \\
\hline $\mathrm{Ba}$ & No & 109 & 690,931 & 340,873 & $-0,281$ & 0,779 \\
& Yes & 3 & 747,267 & 401,600 & & \\
\hline $\mathrm{Cu}$ & No & 109 & 69,951 & 26,858 & $-0,869$ & 0,386 \\
& Yes & 3 & 83,517 & 11,582 & & \\
\hline $\mathrm{Mg}$ & No & 109 & 1607,211 & 228,609 & 0,679 & 0,499 \\
& Yes & 3 & 1517,166 & 39,863 & & \\
\hline $\mathrm{Sr}$ & No & 109 & 781,550 & 199,273 & $-0,685$ & 0,495 \\
& Yes & 3 & 861,833 & 244,717 & & \\
\hline $\mathrm{Ca}$ & No & 109 & 30,542 & 2,378 & 0,731 & 0,466 \\
& Yes & $\mathbf{3}$ & 29,523 & 2,457 & & \\
\hline $\mathrm{Zn}$ & No & 109 & 188,222 & 62,490 & 121,000 (1) & 0,468 \\
& Yes & 3 & 159,150 & 37,153 & & \\
\hline
\end{tabular}

${ }^{1}$ U Mann-Whitney Test 
If now we consider the three different forms of cribra to be pathologies with the same aetiology (Miquel-Feucht et al., 2000) $32 \%$ of the individuals show some kind of cribra (35/108 cases observed). We also observed significantly higher levels of copper in the specimens with cribrn, as related to the age of the individuals, through Student's t-test analysis (Table 6).

Table 6. Statistical values of trace elements and cribra in general and Student's-Test.

\begin{tabular}{llrrrrc}
\hline T. E. & cribra & N & Mean & \multicolumn{2}{c}{$\begin{array}{l}\text { Standard Student's t-test } \\
\text { deviation }\end{array}$} & $\mathbf{P}$ \\
\hline Ba & No & 73 & 678,172 & 331,354 & $-0,582$ & 0,562 \\
& Yes & 35 & 719,130 & 363,617 & & \\
\hline $\mathrm{Cu}$ & No & 73 & 65,631 & 25,896 & $-3,178$ & 0,002 \\
& Yes & 35 & 82,399 & 25,169 & & \\
\hline $\mathrm{Mg}$ & No & 73 & 1600,063 & 220,076 & $-0,060$ & 0,952 \\
& Yes & 35 & 1602,886 & 243,132 & & \\
\hline Sr & No & 73 & 767,059 & 199,317 & $-1,028$ & 0,306 \\
& Yes & 35 & 809,376 & 201,898 & & \\
\hline $\mathrm{Ca}$ & No & 73 & 30,765 & 2,573 & 1,453 & 0,149 \\
& Yes & 35 & 30,050 & 1,951 & & \\
\hline $\mathrm{Zn}$ & No & 73 & 192,042 & 69,680 & $1161,500(1)$ & 0,446 \\
& Yes & 35 & 179,953 & 45,210 & & \\
\hline
\end{tabular}

I U Mann-Whitney Test

One of the possible aetiologies attributed to cribr $a$ is anemia, either of genetic, infectious, or nutritional origin. In this study, it seems likely that the aetiology of the cribrn lesions is not anaemia because in the Prat de la Riba population trace element deficiencies are not present. Moreover, in the sub-adult group, individuals with and without cribra all present higher levels of copper, related to the physiology and diet of this age group.

\section{Conclusions}

In the Prat de la Riba population, a statistical association was evident between the age of the specimens and the levels of only one element: copper. However, the significantly higher level of 
copper in young subadults $(94 \%$ of the individuals with cribra femornlis) can be explained by physiology and/or by a diet rich in cereals during the weaning period. The study showed no associations between cribra and lower levels of strontium, barium, magnesium, calcium and zinc.

Therefore, it does not appear that cribra was related to nutritional deficiencies, at least not those reflected by the trace elements under examination. Further studies are necessary to search for a relationship with population genetics (through DNA analysis), infectious conditions, or other processes which involve bone marrow hyperplasia.

\section{Bibliography}

Angel, J. L. 1966. Porotic hyperostosis, anemias, malarias, and marshes in the Prehistoric eastern Mediterranean. Science, 153 (3737): 760-762.

Angel, J. L. 1971. Lerna: the People. Results of excavation conducted by the American school of Clnssical Stuties at Athcns. Princeton, New Jersey, Smithsonian Institution Press.

Angel, J. L. 1984. Health as a crucial factor in the changes from hunting to developed farming in the eastern Mediterranean. In: Cohen, M. N.; Armelagos, G. J. (eds.) Palcopathology at the origins of agriculture. New York, Academic Press: 51-73.

Baxarias, J. 2001. Estudio paleopatológico de los restos extmmados en la Necrópolis Tartorromana de Prat de la Riba, Tarragona. Zaragoza, Editorial Pórtico.

Campillo, D. 1993. Paleopatología. Los primeros zestigios de la enfermedad. (Printern parte). Barcelona, Fundación Uriach 1838. (Colección Histórica de Ciéncias de la Salud; 4).

Campillo, D. 2001. Introducción a la Paleopatologín. Barcelona, Edicions Bellaterra.

Carlson, D. S.; Armelagos, G. J.; van Gerven, D. P. 1974. Factors influencing the etiology of cribrn orbitalin in prehistoric Nubia. Joumal of Human Evolution, 3 (5): 405-410.

Cohen, M. N.; Armelagos, G. J. (eds.) 1984. Palcopathology at the origins of agriculture. New York, Academic Press. 
El-Najjar, M. Y. 1976. Maize, malaria and the anemias in the PreColumbian New World. Yearbook of Physical Anthropology, 20: 329-337. El-Najjar, M. Y.; Lozoff, B.; Ryan, D. J. 1975. The paleoepidemiology of porotic hyperostosis in the American southwest: radiological and ecological considerations. American Journal of Roentgenology, Radimm Therapy and Nuclear Medicine, 125(4): 918-924.

El-Najjar, M. Y.; Robertson, A. L. 1976. Spongy bones in prehistoric America. Science, 193 (4248): 141-143.

El-Najjar, M. Y.; Ryan, D. J.; Turner II, C. G.; Lozoff, B. 1976. The etiology of porotic hyperostosis among the Prehistoric and Historic Anasazi Indians of Southwestern USA. American Joumal of Physical Anttropology, 44(3): 477-488.

Fairbanks, V. F.; Beutler, E. 1972. Erythrocyte disorders - anemias related to disturbance of hemoglobin synthesis. In: William, W. J.; Beutler, E; Erslev, A. J.; Rundles, R. W. (eds.). Hematology. New York, McGrawHill: $305-326$.

Foguet, G.; Vilaseca, A. 1995. Els enterraments del carrer Prat de la Riba / Ramón y Cajal: un nou sector excavat de la necròpolis del Francolí. Citerior, 1: 151-171.

Fornaciari, G.; Mallegni, F; Bertini, D.; Nuti, V. 1981. Cribrn orbitalia, and elemental bone iron, in the Punics of Carthage. OSSA, 3: 63-77

Garcia, E.; Subirà, M. E. 2001. Dieta y sociedad en Can Reinés (análisis de elementos traza en una necrópolis del 600 d.C.). Revista Española de Antropologín Biológica, 22: 107-114.

Gilbert, R. I. Jr. 1985. Stress, paleonutrition, and trace elements. In: Gilbert, R. I. Jr.; Mielke, J. H. (eds.). The analysis of Prehistoric diets. Orlando, Academic Press: 339-358.

Glen-Haduch, E.; Szostek, K.; Glab, H. 1997. Cribra orbitalia and trace element content in human teeth from Neolithic and early Bronze age graves in southern Poland. American Jowmal of Plyysical Anthropology, 103(2): 201-207.

Hengen, O. P. 1971. Cribra orbitalia: pathogenesis and probable etiology. Homo, 22: 57-75.

Hühne-Osterloh, G.; Grupe, G. 1989. Causes of infant mortality in the Middle Ages revealed by chemical and palaeopathological analyses of skeletal remains. Zeitschrift fiir Morphologie und Anthropologie, 77(3): 247-258.

Lallo, J. W.; Armelagos, G. J.; Mensforth, R. P. 1977. The role of diet, disease, and physiology in the origin of porotic hyperostosis. Human Biology, 49(3): 471-483. 
Lambert, J. B.; Weydert-Homeyer, J. M. 1993. The fundamental relationship between ancient diet and the inorganic constituents of bone as derived from feeding experiments. Archacometry, 35(2): 279294.

Miquel-Feucht, M. J.; Polo-Cerdá, M.; Villalaín-Blanco, J. D. 2000. El sindrome criboso: criba femoral vs criba orbitalia. In: Sánchez Sánchez, J. A. (ed.). Actas del V Congreso Nacional de Paleopatologín. Alcalá la Real, Asociación Española de Paleopatología y Ayuntamiento de Alcalá la Real: 221-237.

Moore, S. 1929. The bone changes in sickle cell anemia with a note on similar changes observed in skulls of ancient Mayan Indians. Joumal of the Missouri Medical Association, 26: 561-564.

Price, T. D.; Kavanagh, M. 1982. Bone composition and the reconstruction of diet: examples from the Midwestern United States. Midcontinent Journal of Archneology, 7(1): 63-79.

Salvadei, L.; Ricci, F.; Manzi, G. 2001. Porotic hyperostosis as a marker of health and nutritional conditions during childhood: studies at the transition between Imperial Rome and the Early Middle ages. American Joumal of Human Biology, 13(6): 709-717.

Schutkowsky, H. 1993. Sex determination of infant and juvenile skeletons: morphognostic features. American Journal of Physical Anthropology, 90(2): 199-205.

Smith, C. H. 1954. Anemias in infancy and childhood: diagnostic and therapeutic considerations. Bulletin of the New York Acatenty of Medicine, 30(3): 154-183.

Smrčka, V.; Jambor, J.; Salas M. 1989. Trace elements in paleopathology of human diet. In: Capasso, L. (ed.). Advances in Paleopathology. Chieti, Marino Solfanelli Editore.: 181-184. (Journal of Paleopathology. Monographic Publications; 1 ).

SPSS Inc., 2001. SPSS for Windorus-relense 11.5.1. Chicago.

Stuart-Macadam, P. 1982. A correlative study of a paleopathology of the skull. PhD dissertation, Department of Physical PAnthropology, University of Cambridge.

Stuart-Macadam, P. 1992. Anemia in past human populations. In: StuartMacadam, P; Kent, S. (eds.). Diet, demography and disense: changing perspectives on anemia. New York, Aldine de Gruyter: 151-170.

Subirà, M. E. 1993. Elementos traza en restos humanos Talayóticos. Zaragoza, Libros Pórtico. 
Subirà, M. E.; Alesan, A.; Malgosa, A. 1992. Cribra orbitalia y déficit nutricional. Estudios de elementos traza. Munibe, 8: 153-158.

Subirà, M. E.; Garcia, E. 2003. Estudi de la dieta: la població de Can Martorell des de l'anàlisi dels elements traça. Laietnnin, 14: 163-170.

Von Endt, D. W.; Ortner, D. J. 1982. Amino acid analysis of bone from a possible case of Prehistoric iron deficiency anemia from the American Southwest. American Journal of Physical Antiropology, 59(4): 377-385.

Waldron, T. 1987. The potential of analysis of chemical constituents of bone. In: Boddington, A.; Garland, A. N.; Janaway, R. C. (eds.). Death, decay and reconstruction: appronches to archaeology and forensic science. Manchester, Manchester University Press: 149-159.

Weinberg, E. D. 1974. Iron and susceptibility to infectious disease. Science, 184: 952-956. 